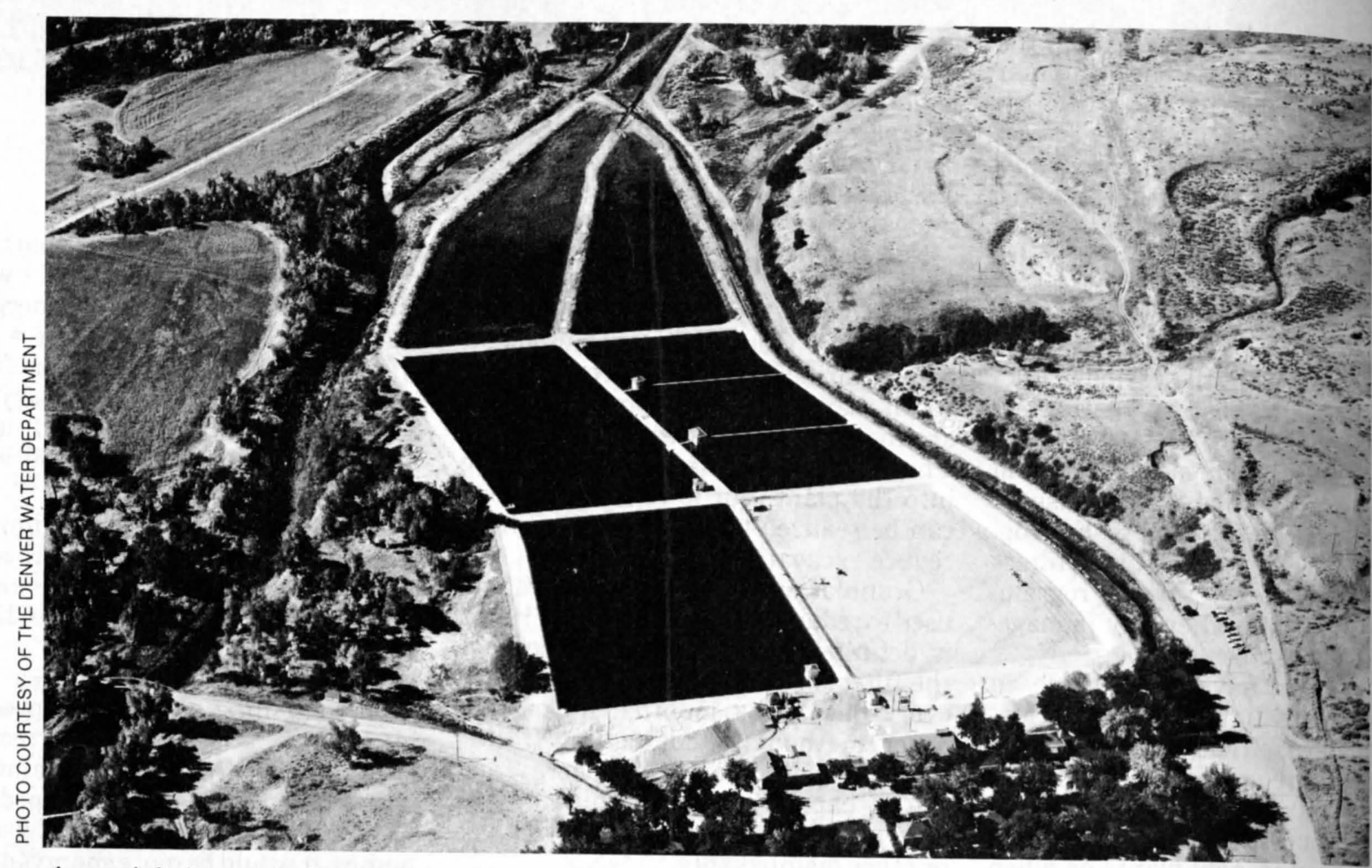
An aerial view of the Kassler slow-rate sand filtration plant shows the six basins with one basin emptied for
scraping. This plant has served the Denver Water Department for more than 80 years.

\section{The Application and Effectiveness of Slow Sand Filtration in the United States}

Lloyd A. Slezak and Ronald C. Sims

A survey of 27 slow sand filtration plants in the United States indicated that most of these years old, and are effective and inexpensive to fower than 10000 persons, are more than 50 in Logan, Utah, was compared with the operating plants to determine if locally available,
unsieved sand achieved similar results. The $75-\mathrm{m}^{3} / \mathrm{d}$ research facility performed well in removing turbidity, coliform bacteria, and particles of a size representative of Giardiacysts.

Slow sand filtration for providing biologically active top layer of sand is potable water has been used since the scraped away.

nineteenth century. However, this tech- Because small communities in the the Uny not now as widely applied in United States cannot take advantage of tion. Slow sand filters are operated at the economies-of-scale associated with filtration rates between operated at rapid sand filtration, slow sand filtration $\mathrm{m}^{3} / \mathrm{h} / \mathrm{m}^{2}$ of filter area, whereas rapid for treatment of sand filtration uses filtration rates be- munity drinking water and rural com tween 5 and $15 \mathrm{~m}^{3} / \mathrm{h} / \mathrm{m}^{2}{ }^{1}$ Slow sand ingly, the research described in this filters treat low-turbidity waters $\quad<10$ article was conducted to investigate the ntu) for weeks or months before accumu- limitations and potential benefits lated materials clog the top layer of using slow sand filters for small com sand, at which time 1 to $2 \mathrm{~cm}$ of the munity water treatment systems.

38 MANAGEMENT AND OPERATIONS dentified and weresent questionnair Twenty-seven questionnaires were d, either fully or partially complete. article summarizes the responses jose questionnaires. the article discusses a scale slow sand filtration research ity ality with other operating slow filtration facilities. The facility at mas a designed capacity of $75 \mathrm{~m}^{3} / \mathrm{d}$ Nuide performance of slow sand filters. article evaluates the Logan facility treatment plant facilities.

uproach

The survey questionnaire was degred to collect information regarding everal philities, including duidual phoplation served; the alty, and uality of influent and effluent ri: the design of the facilities; the rating practices; and the costs of ratment

roensure a reasonably high percent of return, the questionnaire was ganized simply and required only raightforward responses.

\section{its of the survey}

Geographic distribution of slow sand trtion plants. Table 1 lists the locations ated in the eastern United States. irty-seven percent of the filtration lants in the survey are located in New vik. No other state reported more Th slow sand filtration facilities.
Physical characteristics of slow sand ted thacilies. Survey results indi. tration facilities serve communities of wer than 10000 persons (Figure 1). me 31 percent of the facilities serve pulations of fewer than 1000 persons. me facilities serving larger populause slow sand filters in paralle rapid sand filters that were installed the construction of the slow sand plants. Data collected on plant popula axpected, closely paralled arch facility has. The Logan, Utah, $\mathrm{m}^{3} / \mathrm{d}$, which is significantly less than of the operating slow sand filtration kalities.

Figure 2 shows the distribution of the of the surveyed slow sand filtration iities. Some 56 percent of facilities emore than 50 years old, but there has recent construction activity assoalso with slow sand filtration. Figure re rate of construction of slow sand Water fuacilities declined. aities use lakes or reservoirs as raw

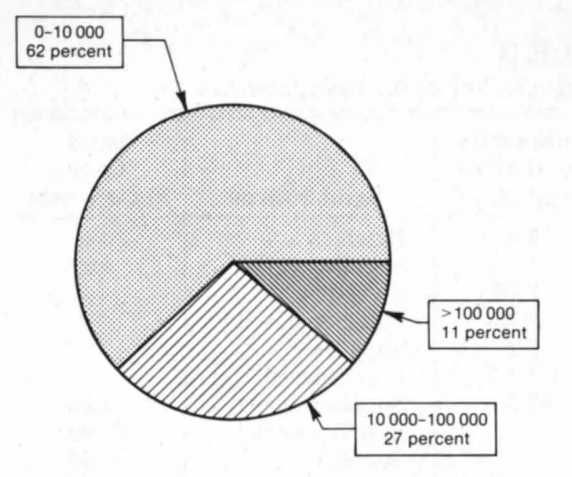

Figure 1. Populations of communitie served by operating slow sand filte

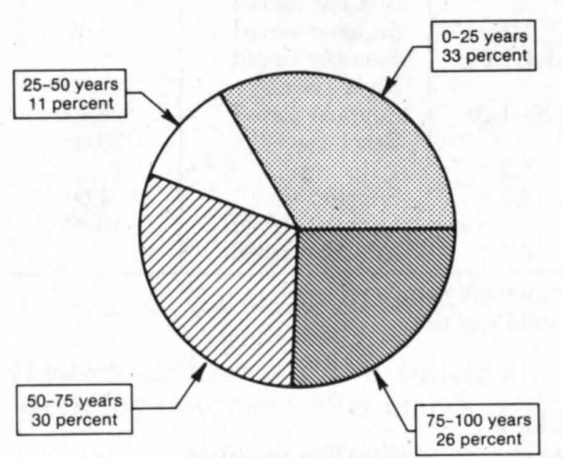

Filter component depths a t w sand filtration

Figure 2. Ages of operating slow sand filtration plants

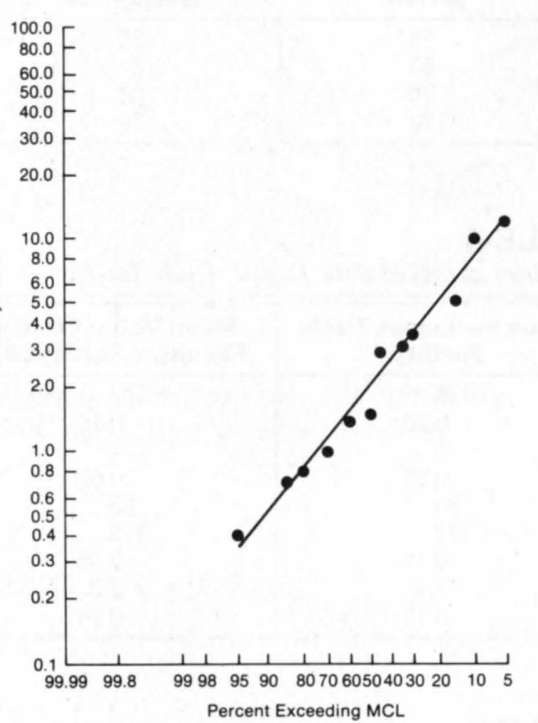

Figure 4. Average raw water turbid ities at operating slow sand filter plants

TABLE 2

\begin{tabular}{|c|c|c|c}
\hline \hline $\begin{array}{c}\text { Filter } \\
\text { Component }\end{array}$ & $\begin{array}{c}\text { Mean Depth } \\
\mathbf{c m}\end{array}$ & $\begin{array}{c}\text { Coefficient of } \\
\text { Variation } \\
\text { percent }\end{array}$ & $\begin{array}{c}\text { Number of } \\
\text { Responses }\end{array}$ \\
\hline Water & 173 & 48 & 25 \\
Sand medium & 84 & 30 & 24 \\
Support media & 56 & 72 & 25 \\
\hline
\end{tabular}

Figure 3. Raw water sources used at (

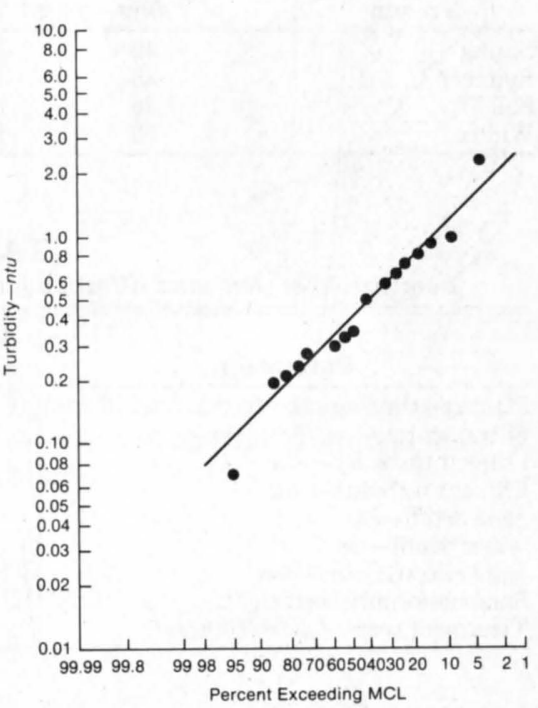

Figure 5. Average filtered water turpigure 5 . Average filtered water turplants

BER 198 
TABLE 3

Sand characteristics at operating slow sand filtration facilities

\begin{tabular}{|c|c|c|c|c|}
\hline Facility & $\begin{array}{c}\text { Effective } \\
\text { Size (D }\left(D_{10}\right)^{*} \\
\mathbf{m m}^{2}\end{array}$ & $\begin{array}{l}\text { Uniformity } \\
\text { Coefficient } \\
D_{60^{\dagger} / D_{10}}\end{array}$ & Sand Source & $\begin{array}{c}\text { Sand } \\
\text { Cost } \\
\text { dollars } / \text { ton }\end{array}$ \\
\hline $\begin{array}{l}\text { Ashland, Wis. } \\
\text { Auburn, N.Y. } \\
\text { Denver, Colo. } \\
\text { Gilbertsville, N.Y. } \\
\text { Hamden, Conn. } \\
\text { Honolulu, Hawai } \\
\text { Ilion, N.Y. } \\
\text { Kelley Island, Ohio } \\
\text { Lanesville, Ind. } \\
\text { Little Falls, N.Y. } \\
\text { Lyndonville, N.Y. } \\
\text { Pawhuska, Okla. } \\
\text { Port Henry, N.Y. } \\
\text { Scranton, Kan. } \\
\text { Shortsville, N.Y. } \\
\text { Stayton, Ore. } \\
\text { Stiliwell, Okla. } \\
\text { Superior, Wis. } \\
\text { Waipio, Hawai } \\
\text { Watsonville, Calif. } \\
\text { Waverly, N.Y. } \\
\text { West Hartford, Conn. } \\
\text { Westfield, Mass. }\end{array}$ & $\begin{array}{c}0.26 \\
0.3 \\
0.34 \\
0.40 \\
0.3 \\
0.45-0.55 \\
0.2-0.4 \\
\\
\\
\\
0.25-0.35 \\
\\
0.35-0.45 \\
1.2-1.4 \\
0.45-0.55 \\
0.3 \\
0.12 \\
0.3\end{array}$ & $\begin{array}{c}2.5-3.5 \\
\\
1.7 \\
1.4-1.6 \\
1.35-1.70 \\
2.3 \\
3.5 \\
2.3\end{array}$ & $\begin{array}{l}\text { Beach } \\
\text { Supplier-sieved } \\
\text { River-sieved } \\
\text { Supplier-sieved } \\
\text { Supplier } \\
\text { Beach-sieved } \\
\text { Supplier-sieved } \\
\text { Supplier-sieved } \\
\text { Supplier } \\
\text { Supplier-washed } \\
\text { Supplier-sieved } \\
\text { Supplier-sieved } \\
\text { Supplier-sieved } \\
\text { Supplier-sieved } \\
\text { Supplier-sieved } \\
\text { Supplier-sieved } \\
\text { River-sieved } \\
\text { Supplier-sieved } \\
\text { Beach-sieved } \\
\text { Supplier } \\
\text { Supplier-sieved } \\
\text { Native, washed }\end{array}$ & $\begin{array}{r}5.00 \\
45.00 \\
28.95 \\
20.00 \\
4.00 \\
10.30\end{array}$ \\
\hline
\end{tabular}

*Size of sieve opening through which 10 percent of sand will pass
†Size of sieve opening through which 60 percent of sand will pass

TABLE 4

Filter cycle durations at operating slow sand filtration facilities

\begin{tabular}{l|c|c|c}
\hline \hline Season & $\begin{array}{c}\text { Mean Length of } \\
\text { Filter Cycle } \\
\text { days }\end{array}$ & $\begin{array}{c}\text { Coefficient of } \\
\text { Variation } \\
\text { percent }\end{array}$ & $\begin{array}{c}\text { Number of } \\
\text { Responses }\end{array}$ \\
\hline Spring & 42 & 73 & 21 \\
Summer & 43 & 63 & 21 \\
Fall & 46 & 70 & 21 \\
Winter & 60 & 72 & 22 \\
\hline
\end{tabular}

TABLE 5

Comparison of slow sand filtration facilities surveyed with Logan, Utah, facility

\begin{tabular}{|c|c|c|}
\hline Parameter & $\begin{array}{l}\text { Value for Logan, Utah, } \\
\text { Facility }\end{array}$ & $\begin{array}{c}\text { Mean Value From } \\
\text { Facilities Surveyed }\end{array}$ \\
\hline 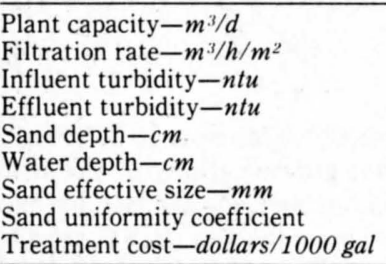 & $\begin{array}{c}75 \\
0.20 \\
5 \\
0.28 \\
30 \\
122 \\
0.18 \\
4.4 \\
0.15 \\
\end{array}$ & $\begin{array}{c}39000 \\
0.15 \\
4 \\
0.65 \\
33 \\
173 \\
0.38 \\
2.3 \\
0.20 \\
\end{array}$ \\
\hline
\end{tabular}

TABLE 6

\begin{tabular}{|c|c|c|c|}
\hline $\begin{array}{c}\text { Sampling } \\
\text { Date }\end{array}$ & $\begin{array}{c}\text { Effluent } \\
\text { Temperature } \\
{ }^{\circ} \mathrm{C}\end{array}$ & $\begin{array}{c}\text { Influent } \\
\text { Total Coliforms } \\
\text { number/100 } \mathrm{mL}\end{array}$ & $\begin{array}{c}\text { Effluent } \\
\text { Total Coliforms } \\
\text { number } / 100 \mathrm{~mL}\end{array}$ \\
\hline $\begin{array}{l}\text { Oct. } 1,1983 \\
\text { Oct. 21, } 1983 \\
\text { Nov. } 1,1983 \\
\text { Jan. 27, } 1984 \\
\text { Jan. 31, 1984 } \\
\text { Feb. 3, } 1984 \\
\text { Feb. 29, } 1984\end{array}$ & $\begin{array}{l}10 \\
10.4 \\
14.4 \\
2.4 \\
1.2 \\
1.1 \\
2.3\end{array}$ & $\begin{array}{r}50 \\
40 \\
30 \\
12 \\
10 \\
4 \\
4\end{array}$ & $\begin{array}{l}0 \\
1 \\
0 \\
0 \\
1 \\
1 \\
1\end{array}$ \\
\hline
\end{tabular}

40 MANAGEMENT AND OPERATIONS groundwater. Some plants reported

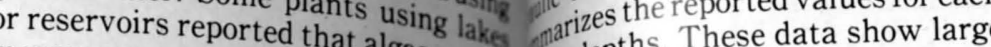
Legan, river as a raw water source. ity removal efficiorted excellent tur. ty res

20. All facilities reported very uniform is and and 0.1 to $0.5 \mathrm{~mm}$. Many facilities

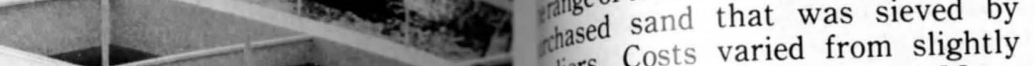
pliers. $\$ 4 /$ ton to $\$ 63 /$ ton. Many int than $\$ 4$ also reported that filter sand, 13. 13 purchased, has never been replaced - $d$ in the Logan facility is the least

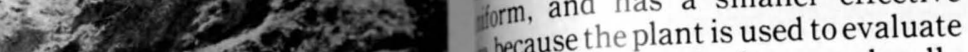
The slow-rate sand filtration experimental plant at Logan, Utah, two-cell filter and a silding, the presedimentation ank.

that about 50 percent of the facilitie had influent turbidity levels at more than twice the maximum contaminant
level (MCL) of 1.0 ntu. Figure 5 shows that fewer than 15 percent of the plants had effluent turbidity levels in excess of the MCL. Turbidity of raw water at the Logan facility varies from 1.0 to $15.0 \mathrm{nt}$ and the effluent turbidity is consistently less than $1.0 \mathrm{ntu}$.

Figures 6 and 7 show coliform removal As with turbidity, all plants reported good performance. Figure 6 shows tha more than 20 percent of the facilities has $100 / 100 \mathrm{~mL}$. Figure 7 indicates that 90 $100 / 100$ th. Facilities reported effluent coliform levels of $1 / 100 \mathrm{~mL}$ or less. Data related to other water quality parameters, such as organic and inor. ganic species, were not requested in the questionnaire. Responses to question in concerning sampling requirements ire dicated that most of these analyses. One
required only a few times a year. required only a few times a influent manga. nese and iron caused operational probnese and iron caused operas not specified
lems. However, it was whether these metals were removed. Design characteristics. Slow sand filDesign characteristics. Slow a relative
tration is characterized by a with other simplicity of design compared with other water treatment processes. Typically, slow sand filtration units consist or (1) depth of graded gravel, called suppor media, that separates filter sand filter the underdrains; (2) a depth of scrap sand (which may vary because of water ing operations); and (3) a depth or wates hy above the filter sand that provides hy

ose-up view of the experimental rate sand filter shows the two. rage-sedimentation tank at Wonged filtration facilities result in sure 8 shows the distribution of filtraiy was $/ \mathrm{h} / \mathrm{m}^{2}$. The $20 \mathrm{~m} \mathrm{~m}^{3} / \mathrm{h} / \mathrm{m}^{2}$.

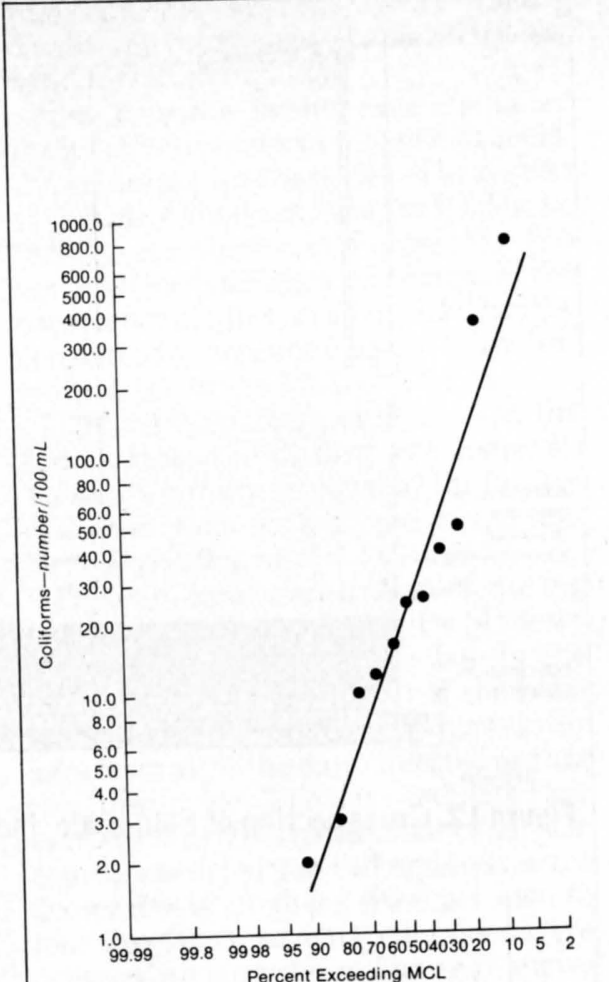

wow sand filtration facilities result in in rates used at slow sand filtration inties. Figure 8 also shows that most an maintain filtration rates of less ter cycle durations should be extive have significant effects on the er scrapt and ease of operations. filter ing, required at the end of vity. It is usually performed with shovels, asually performed with JOURNAL AWWA ECEMBER 198
Figure 6. Coliforms in raw waters at Figure 6. Coliforms in raw waters

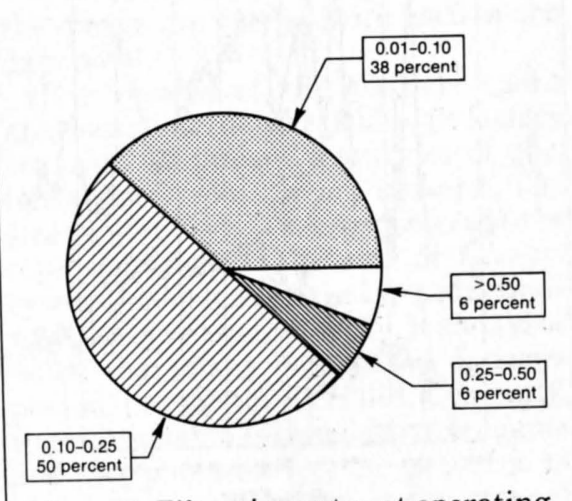

Figure 8. Filtration rates at operating slow sand filter plants $-m^{3} / h / m^{2}$

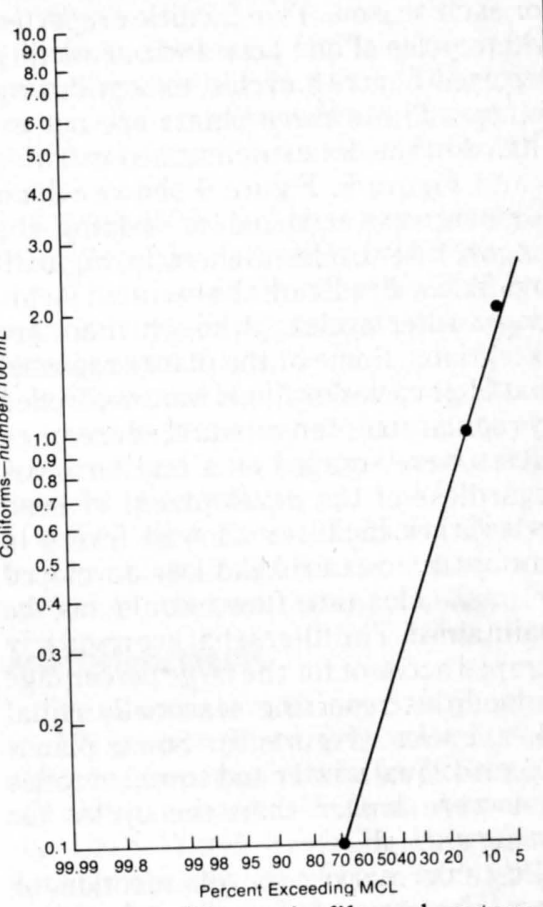

Figure 7. Coliforms in filtered waters toperating slow sand filter plan

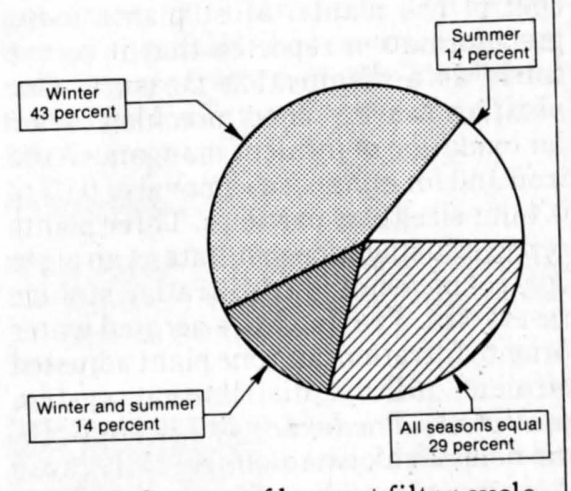

Figure 9. Season of longest filter cycle duration at operating slow sand filter plants

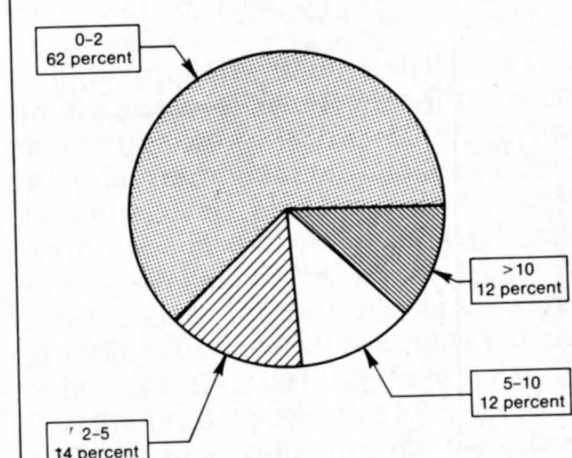

Figure 10. Numbers of personnel Figure 10. Numbers of personnel employe
plants

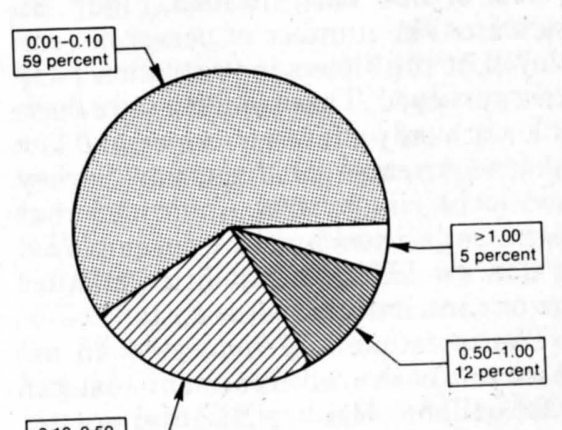

\begin{tabular}{l}
$0.10-0.50$ \\
24 percent \\
\hline
\end{tabular}

Figure 11. Cost of treatment at operlars/1000 gal 
have developed custom methods using
power tractors. Table 4 shows power tractors. Table 4 shows mean for each season. Two facilities reported filter cycles of one year and one facility reported 6-month cycles, except during winter. These three plants are not in cluded in the data summarized in Table 4 and Figure 9. Figure 9 shows which lons and Table 4 indicate Generally, Figure 9 longer filter cycles, that winter yields exceptions. Some of the plantsere are that filter cycle durations were controlled by regular maintenance procedures; i.e., filters were scraped on a regular basis regardless of the development of head run until a certain head loss developed or until adequate flows could not be maintained. The filters that are regularly of faciliticsure filter cycles (Figure 9). Somently equal reported equal winter and. Some plants that were longer than the cycles for spring and fall.

Postchlorination for disinfection filter effluent was practiced by 93 percent of the facilities studied in the survey. Prechlorination was reported at 22 perprechlorination reported that it served solely as a disinfection measure. One plant, however, cited prechlorination for oxidation of influent manganese and iron and for enhanced removal of 0.02 to reported using copper sulfate Three plants ontrol measure in prefiltration storage reservoirs. Two facilities aerated water prior to filtration, and one plant adjusted prouent $\mathrm{pH}$ for distribution system protection. The facility at Logan, Utah, was a rhlorine disinfection because discharge to public supplity and did not presedimentation reduced suspended material

Cost of slow sand filtration. Figure 10 indicates the num ployed at the slow sand filtration facilities surveyed. These facilities are operable with only a few personnel, and low responses, in general, indicated tha responses, in general, indicated that at slow sand filtration facilities, another factor contributing to locilies, another The questionnaire requests.

essment of overall treatment an as 1000 gallons. Many plants did cost pe spond to this request because of lack compile a cost estimate. Figure 11 (um most plants achieve treatment for less report was $\$ 6.50 / 1000$ hal and treatment cost of

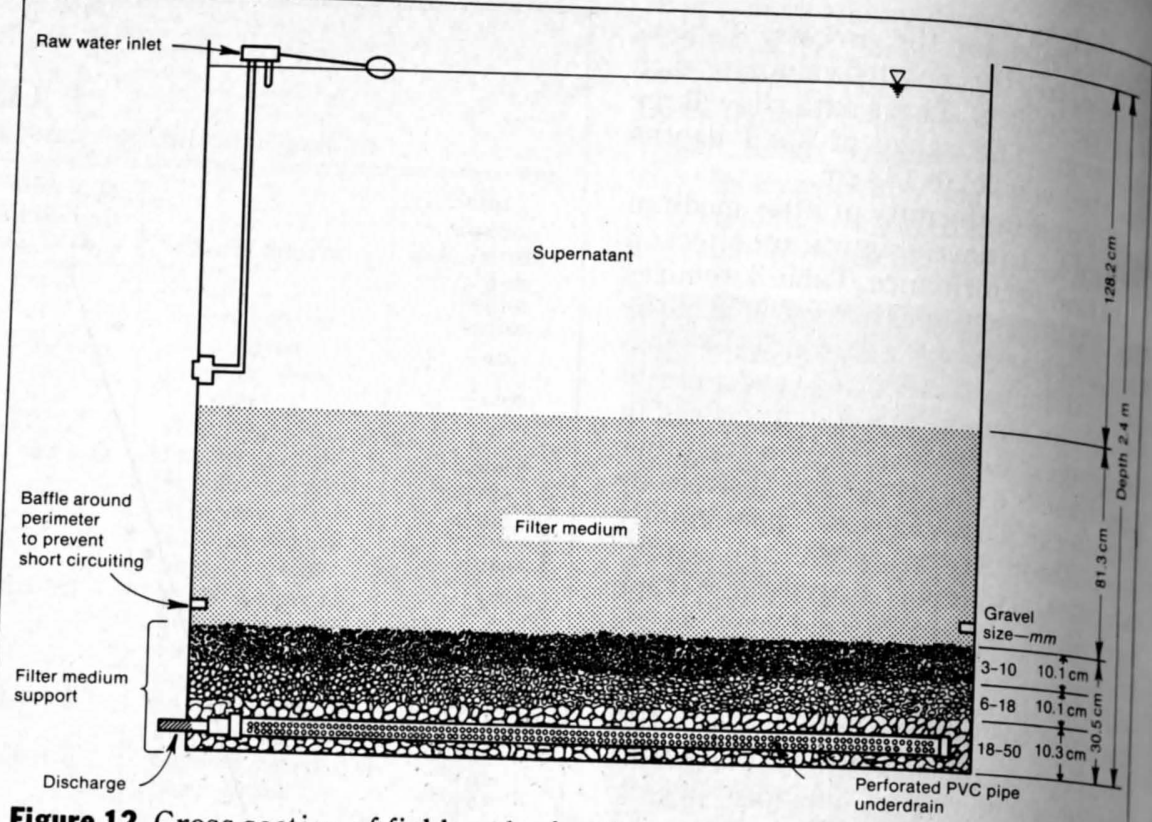

Figure 12. Cross section of field-scale facility

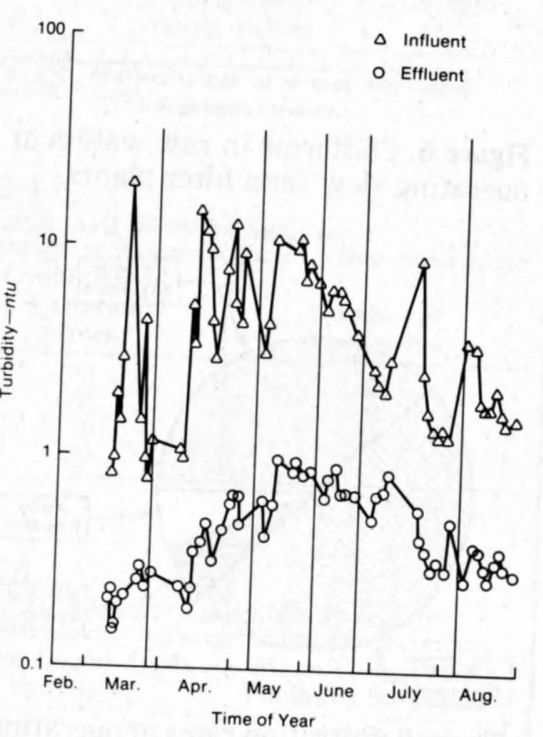

Figure 13. Turbidity data from field scale facility (vertical lines indicate
duration of filter cycle)

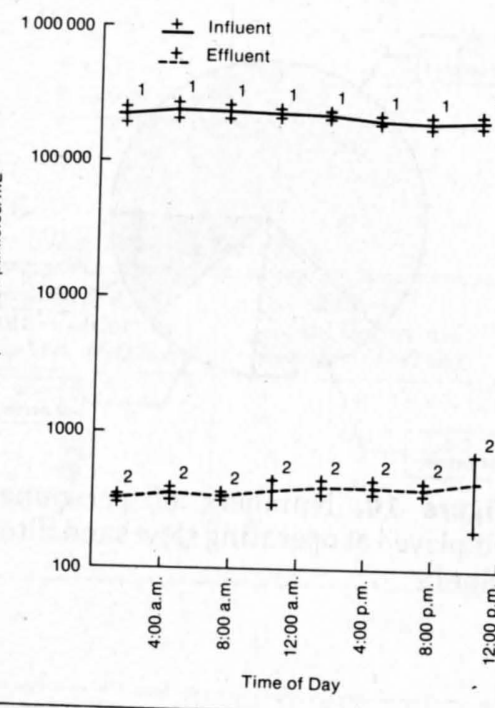

statistically the same at 0.05 level significance) and filtration because of excessive was expressed. The Logan facility's design life, was estimated to be do00 gal.

mall communities do not

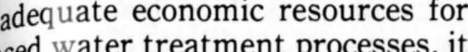
propriate to evaluate slow san as an alternative treatment hod for such communities. Since nunities, the proposed application stified. Most operating facilities rted successful performance without hation. The plants had few compo and seemed to be relatively easy to Many of the facilities were from to 100 years old, indicating long tof less than $\$ 0.10 / 1000$ gal. Assum. zwater use of $378 \mathrm{~L} / \mathrm{d}$ per capita $(100$ d), a cost to the individual user of
nut $\$ 0.01 / \mathrm{d}$ is indicated. Generally, esurvey did not provide any evidence anst using slow sand filtration for all communit

The facility at Logan, Utah, is intended provide long-term operational data on ow sand filtration under controlled ditions. The facility is discussed for purpose of comparing it with operpresented by the survey responses. If
Logan facility is typical of other te Logan facility is typical of other eplaced in the long-term data collected tom the facility.

The facility at Logan consists of two ration cells, each with a filtration rea of $9.3 \mathrm{~m}^{2}$. Each cell is an independent itration unit so that controlled experints can be conducted. A cross section
filtration cell is shown in Figure 12 a filtration cell is shown in Figure 12 . -h detention time, was provided an be optionally included in the treatsed as a raw water source. The Logan Viver is a watershed conduit for nountain canyon. The filtration facility Socated at the mouth of this canyon. lable 5 compares performance and de ith parameters in the Logan facility arameters collected from the survey. able 5 indicates that the Logan facility cility. The sand used in this facility is, ver, less uniform and of a smaller ctive size than those reported in lity is being used to evaluate the information that can be useful in uating the effects of varying climaEMBER 1984 acy of using sands of lower than

tological and influent water quality sand filtration facilities.

for its effective facility was evaluated Logan research facility are listed able 6. Coliform removal by the facility

Particle data we collected during the distribution of particle size in the influent and in the effluent of the field. counts occurred for the smallest sizes detected and three-log (99.9 percent) to our-log (99.99 percent) reductions were the results of particle counts grouped by time of day for the $7-12-\mu \mathrm{m}$ size range. The 95 percent confidence intervals for nalyses show that the field-scale facility removed significant quantities of particles sized from $2.4 \mu \mathrm{m}$ upward. The size range of $7-12 \mu \mathrm{m}$ is considered to be cysts. were Conserved in this study. It should noted that many small-sized particles passed through the filter bed. Currently, the relationship between particle counts and the potential for the presence of pathogens is unknown. If the ratio of inert particles to pathogens remains the same through filtration, these data ind cate that significant reduction in path-gens can be ach a minimum amount an attempt to scrape new filter cycle. Many other factors tha were not controllable in the field-scale facility probably affected the length of filter cycles. Influent turbidity, alga growth, and temperature are all expected to have an effect on filter cycle duration. The limited data collected from the field scale facility thus far do not allow most strongly influences filter cycle

\section{Conclusions} conditions on the performa ty coliforms, and particles. The turbidof turbidity analyses from the field-scale acility are shown in Figure 13. The vertical lines in Figure 13 represent the occurrence of filter scraping. The facility consistently produced water with t

The total coliform analyses for the was good, even with a sand media un Particle data were. (Table 5). cale facility. The data shown are averges from all of the data collected during the filter cycle. The data indicate that wo-log (99 percent) reductions of particle the means are plotted with each of th data points.

The results of the particle count

Filter cycle durations lasted from two durations.

- Operating slow sand filtration facilmunities with populations of fewer than

- Most slow sand facilities are more theen a relatively significant, there has low sand filter construction during the last 25 years.

- Most slow sand facilities operateat filration rates of less than $0.25 \mathrm{~m}^{3} / \mathrm{h} / \mathrm{m}^{2}$. - The longest filter cycle durations occur during the winter months at most

low sand facilities.

- Slow sand facilities are inexpensive to operate because few personnel are only a minimal

- The slow sand filtration research .

\section{Acknowledgments}

The authors thank Gary S. Logsdon of e US Environmental Protection Agency of Utan Water conated the 列 the Division of Environmental Engineering and the Utah Water Research aboratory at Utah State University with the operators of the slow sand filtration facilities discussed in this .

\section{Refence}

HuISMAN, L. \& WooD, W.E. Slow Sand Geneva, Switzerland (1974).

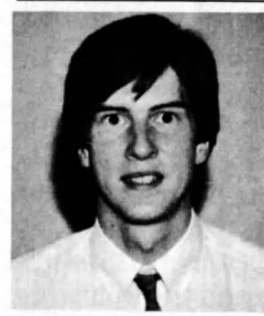

About the authors: Slak is an nvironmental engi. teer, specializing in with Strand Astems, ciates Inc., $910 \mathrm{~W}$ Wingra Drive, Madi. conducting the research described in this article, he was a graduate research assis. tant at the Utah Water Research Labora. tory in Logan. A member of $A W W A$ and $W P C F$, he has a master's degree from Utah State University, Logan, and a bachelor's degree in civilengineering from the University of Wisconsin, Madison. Ronald C. Sims is head of the Division of Environmental Engineering at Utah State Universily, UMC 82, Logan, UT 84322. and hazardous waste treatment and con ducts research at the Utah Water Research Laboratory. Currently he is working with private industry and the state of Utah to

The following conclusions were develop slow sand filtration systems for small communities.

L.A. SLEZAK \& R.C. SIMS 43 